Mengxing FU

Shanghai International Studies University

Shanghai, China

echofu@shisu.edu.cn

\title{
NEW WINE IN OLD BOTTLES: CONTEMPORARY CHINESE ONLINE ALLEGORICAL GHOST STORIES AS POLITICAL COMMENTARY
}

Recommended Citation: Fu, Mengxing. "New Wine in Old Bottles: Contemporary Chinese Online Allegorical Ghost Stories as Political Commentary." Metacritic Journal for Comparative Studies and Theory 5.1 (2019): https://doi.org/10.24193/mjcst.2019.7.02

\begin{abstract}
The phenomenal popularity of the Internet literature in China and the potential for freedom of speech in China's cyberspace have long fascinated scholars of contemporary China. This article examines the interaction between Chinese Internet literature and the ever-increasing online censorship by focusing on one type of Internet literature in China: the allegorical ghost stories. While observers of censorship in China have expressed worries about the tightening censorship in China's cyberspace and self-censorship's damaging effect on literature, this article follows the conceptualization of censorship as co-existing with literary production and seeks to explore how censorship shapes literature. Specifically, it analyses how the contemporary online allegorical ghost stories re-appropriate an old Chinese fictional genre zhiguai (i.e. records of the strange) - a genre that has maintained a paradoxical dissenting and conforming relationship with the state orthodoxy - and use a coded, "Aesopian language" to satirize contemporary Chinese politics and revisit historical atrocities. I argue that these negotiations with censorship (or selfcensorship) resurrect the premodern zhiguai, turning it into a historical documentation of the contemporary and constitute a form of resistance that smuggles into the public discourse a usually hidden transcript.
\end{abstract}

Keywords: Internet, censorship, Internet literature, ghost stories, China, zhiguai 
The phenomenal popularity of Internet literature in China (around $48 \%$ of Chinese Internet users accessed applications providing online literature in 2017') and the freedom of speech and its curtailment in China's cyberspace have been two subjects fascinating scholars of contemporary China. This article focuses on the interaction between Chinese Internet literature and the ever-increasing online censorship by examining one type of Internet literature in China: the allegorical ghost stories. While observers of China's censorship in the Internet age have expressed worries about the shrinking room for expression in the cyberspace and self-censorship's damaging effect on literature (Wacker 379; $\mathrm{Ng} 242$ ), this article follows the conceptualization of censorship as co-existing with literary production and seeks to explore how censorship shapes literature. Specifically, it examines how the contemporary online allegorical ghost stories re-appropriate an old Chinese fictional genre zhiguai (i.e. records of the strange) - a genre that has maintained a paradoxical dissenting as well as conforming relationship with the state orthodoxy and uses a coded, double-structured "Aesopian language" 2 to satirize contemporary political campaigns in China and to revisit historical atrocities. I argue that these negotiations with censorship (or self-censorship) resurrect the old zhiguai, turning it into a relevant historical documentation of the contemporary.

In order to understand the socio-political context in which Chinese Internet literature flourishes, it is necessary to first briefly survey the systematic censorship of literature in post-socialist China. Unlike Western countries, where direct state censorship of cultural products is limited and well-delineated in legislative instead of moral terms, China is a country where the guidelines for censorship have never been made clear (Ng 242) and where pre-publication censorship is carried out through the so-called "book-number system": every book or periodical needs to obtain an official

${ }^{1}$ The data come from the $41^{\text {st }}$ Statistical Report on Internet Development in China (58), issued by China Internet Network Information Center (CNNIC), an official organization authorized by the State Council to serve as the "constructor, operator and administrator of infrastructure in Chinese information society". Internet literature has always been an important category of user application in CNNIC's reports, and although the annual increment of online literature users has fallen behind other Internet applications in recent years, as Michelle Hockx notes, the fact that such surveys include a section for online literature testifies to the prevalence of this phenomenon which has no equivalent in Western societies (3).

${ }^{2}$ I borrow the term "Aesopian language" from Lev Lossefwho, in his study of Russian literature under ideological censorship, defines Aesopian language as "a special literary System, one whose structure allows interaction between author and reader whilst concealing inadmissible content from the censor (x). 
book registration number (similar to ISBN) from the General Administration of Press and Publication 3 before it can be legally published, and books published without an official book number are illegal in nature. The quota for book numbers issued each year is limited and these are allocated only to state-owned publishers. Although, since the economic reform of the 1980s, the cooperation and trading between the "second channel," or private entrepreneurs, and state-owned publishers have to some extent undermined the state monopoly on publishing and greatly expanded the variety of books published (Kong 72-5, Berg 326-7, Hockx 27-8), the existence of the book-number system and book editors working as censors means that the threshold for publication in China is still extremely high.

Against this background, the advent of Internet literature 4 in China since the mid-1990s offers aspiring writers a way to partially bypass the strict publication screening in the print industry. China's Internet literature originated in the $1990 \mathrm{O}$ with online magazines and personal literary websites launched by overseas Chinese students; by the early 2000 s emerging literary websites and blogs had begun to contest the hegemony of the print culture in the literary market (Yang 335-7). By now, the highly successful paid-subscription system employed by Internet literature conglomerates like Shenda Interactive has established a stable bond between readers, authors and literary websites (see Hockx 110 on this business model), and Internet literature in China has earned itself a respectable place in contemporary popular culture, its influence testified in the popularity of films and TV serial dramas adapted from original web novels in recent years and in overseas fan forums devoted to Chinese web fiction like Wuxia World5.

While the tremendous success and popularity of Chinese Internet literature seem to suggest a literary boom outside of the tight publication control of the state, and Internet literature's concentration on fantasy, homosexual romance

3 This organization has been merged into the newly established State Administration of Press, Publication, Radio, Film, and Television of People's Republic of China (SAPPRFT) since 2018.

4 Internet literature (or variously called online literature) in this article is understood as literature originally published in an online context and intended to be read by Internet (whether PC or mobile phone) users. Although scholars (Yang 336; Hockx 6-7) of Chinese Internet literature have observed that Chinese Internet literature in format and style is similar to print literature (unlike in the West where an adjacent genre the "electronic literature" tends to be more experimental in form), I hold that the different publication standards in the print and Internet culture do mean that the two forms of literature show different orientations of subjects and style.

5 Introducing itself as "Chinese Fantasy Novels and Light Novels," Wuxiaworld.com < https://www.wuxiaworld.com/> is an English language website where English translations of popular Chinese fantasy novels and original works inspired by this Chinese genre are shared. 38 
(predominately BL, "boys' love"), light erotica - fictional genres that probably would be frowned upon by print publishers - does transgress the usual acceptability of print culture, tightening and innovated control of online publication in recent years in China ${ }^{6}$ makes it doubtful as to how free a space the Internet is for literary production. Gudrun Wacker, drawing on Lawrence Lessig's theory of regulation in the cyberspace, argues that censorship in the Internet age is encoded in the level of infrastructure of the web, and by policing Internet Content Providers (ICP) and Internet Service Providers (ISP), censorship can be carried out effectively and insidiously (358). Indeed, as regulations of the Internet in China since 2000 s have generally held ICPs liable for the contents published on their sites (Wacker 367), a campaign called "Cleansing the Internet" (mainly targeted at violent and pornographic materials) was carried out effectively in 2014 after the 18th Congress of the Communist Party of China, during which many websites concentrating on providing erotic literature were banned and, when they returned to service7, forced to command their authors to remove or revise the materials deemed inappropriate. In this environment, it is reasonable that authors and literary websites are coerced to perform self-censorship, which according to Lynda $\mathrm{Ng}$ is even more insidious and damaging to literature, for the traces of effacement are never there in the first place (242).

However, while the state's campaign to cleanse the Internet did shrink the opportunity for boundary transgression in typical web fictional genres published in those literary portals, the censorship's effect on the type of online literature that I am examining in this article is somehow different. The online allegorical ghost stories I focus on here are not published in websites predominantly devoted to literature, and what may be deemed offensive in them is not pornography but their political satire. In order to communicate to the reader their political satire and to evade censorship at the same time, the authors of these ghost stories re-appropriate an old Chinese fictional genre zhiguai (i.e. records of the strange) and veil their political discontents in the stories' fantastic, sometimes bizarre subjects. What they achieve is a highly

${ }^{6}$ Apart from directly filtering online publication, the state controls Internet contents providers by introducing a license system and by holding these service providers liable for contents published on their portals.

7 Even major portals like Sina.com had its Internet publishing and broadcasting licenses temporarily revoked during the campaign. See an online news article "《Cleansing the Internet》: Multiple Ministries Cooperate to Strike the Original Sin of the Internet” (“净网行动”冲击波 多部委联 合打击互联网原罪) (April 28th 2014) for an introduction of the campaign. 
innovative reformation of classical literature with a poignant modern flavour.

In the following, I will focus on two collections of ghost stories by contemporary web writers Ma Boyong and Jinyi, respectively. Ma is the more famous one and by now quite an established genre fiction writer in China, in both the Internet and print literary markets. He first made a name for himself in the early 2000 on several popular online forums and published his first novel in 2005. But, unlike those writers contracted with big literary websites like Qidian.com, Ma's subsequent novels and short stories have all been published by print publishers while he himself keeps a flamboyant persona and strong connection with his fans on major online platforms like Weibo.com. Indeed, one of the major differences between the ghost stories studied here and those colossal web novels which seem to be the dominant mode of Chinese Internet literature is that the stories of Ma and Jin do not belong to the paidsubscription system of commercial literary websites but are initially published by their writers in their own online social network portals. Ma published a series of ten stories during 2012-2017, loosely collected under the title New Records of the Strange (Xin zhiyi), first in his personal column on Zhiu.com, a Quora-like Q\&A forum where famous users like Ma could attract a large number of fans and may establish their own columns, and Jinyi published his stories in a personal column called "Records of Oxen and Snakes" on Douban.com, a large comprehensive online forum combining disparate functions like books, films, and music ratings, BBS chatrooms, Twitter-like social networks, personal blogs, Amazon-like e-book market, and an original Internet literature section. Zhihu.com and Douban.com are primarily social networks but, having a large number of highly-productive users, they gradually turn into content generating websites. Thus, literary pieces published in an author's personal portal on these sites like the ghost stories I examine here are different from web-novels in portals like Jinjiang.com or Qidian.com in that they are situated in an intermediate terrain between a literary product meant for the public consumption and a personal diary belonging to an individual's blog8. The writers' popularity on these social networks may win them higher publicity than personal blogs and a wider transmission, yet their semi-personal nature may also mean that they are less likely to be targeted by Internet police and thus trigger censorship.

The new transmission channels aside, these ghost stories bear another

8 Jinyi's column was initially offered without charge, but it lately requires a small payment for the whole package. 
significant similarity: they are ostensibly modelled upon a classical literary genre with a history of over a thousand years in China, i.e. zhiguai, the records of the strange ${ }^{9}$. With a deliberate mingling of zhiguai conventions and issues of contemporary concern, these stories create a double-structure, directing the reader's attention to the surface fantastical, humorous, and sometimes bizarre plot while simultaneously veiling and disclosing the factual, satirical and subversive core. According to Lev Lossef, a contrast or conflict between the different artistic elements of a literary text as well as between the text and its cultural-political environment is key to Aesopian language as a metastyle, as it is this discrepancy that draws the reader's attention to a subtext which may be the target of censorship (23). In the case of my analysis, it is the contrast between the old zhiguai form and the sensitive contemporary issue that serves both as the "screen" - "literary devices bent on concealing the Aesopian text" (Lossef 52) - and the "marker" - "literary devices that draw attention to that same text" (Lossef 52) - which make up the double-structure of the Aesopian text. Indeed, to satire, to ridicule, and to subvert is also one of the original functions of the genre zhiguai as I will explain below, so the combination of familiarity and unexpectedness in these allegorical stories not only makes them more entertaining but is also key to the covert interaction between the author and the intended reader, both acting with a keen awareness of the censor's possible persecution. Viewed from a political perspective, these new appropriations of an old form constitute a type of subordinate discourse situated strategically between what James C. Scott designates as the public transcript that reflects the ideology of the powerful and the hidden transcript of the subordinates which contains sentiments of rebellion and dissent (19). According to Scott, this intermediate, third realm of expression is significant as a form of resistance because it is placed sufficiently in the public view, yet is so coded that it carries with it the dissident message from the hidden transcript.

Zhiguai as a literary genre is almost as old as Chinese fiction ${ }^{10}$. Originating in the chaotic Six Dynasties period (220-589 A.D.), they were first penned by the group

9 Here it needs to be pointed out that ghost story may not be a name doing perfect justice to this online fiction, for neither zhiguai nor these stories are invariably about ghosts, but since the ghost story is the usual English term used for the most approximate category of fantastical stories, I adopt the name and use it in a broad sense as it is used in Julia Briggs' Night Visitors: The Rise and Fall of the English Ghost Story.

10 According to Dewoskin (1977), "The Six Dynasties Chih-Kuai and the Birth of Fiction," the emergence of zhiguai marked the birth of Chinese fiction out of historiography. 
of literati (often court or private historians) who felt the order of their world was collapsing and new orders needed to be created or discerned from the behaviour patterns of gods and ghosts. Hence the genre is predominately dedicated to recording the strange - stories of gods, ghosts, demons, karmic retribution, and transmigration, - and many of them are allegorical in nature: admonishing people by examples of the supernatural (Liu 297). As the first authors were themselves historians, they borrowed heavily from the style of historiography in creating this new fictional genre and gradually moved it away from its neighbour in the historiographic section, zhiren (i.e. "records of people" or biographies). The fact that these zhiguai collections were not removed from the "history" category of the traditional Chinese bibliographical system until the Tang Dynasty (816-903 A.D., $\mathrm{Lu} 3$ ) testifies to the affinity between the two genres, and this affinity has a longlasting impact on the discursive function of zhiguai. As a "corrupted" form of history and a genre of forbidden subjects under Confucian orthodoxy ${ }^{11}$, zhiguai maintains a paradoxical centripetal and centrifugal force vis-a-vis the orthodox discourse in the power center: on the one hand, it endeavours to be recognized by the orthodox as a useful minor discourse, a supplementary history by historians of the strange, while on the other hand, it is wild and riotous, an unofficial history likely to contradict and disrupt the hegemony of the official history. This paradoxical nature of zhiguai is poignantly felt in the Qing-dynasty zhiguai masterpieces - Records of the Strange from the Liao Studio (Liaozhai zhiyi, prefaced 1715) ${ }^{12}$ and What the Master Did Not Talk About (Zibuyu ca. 1788)13 - which are also the direct influence of the contemporary ghost stories examined in this article.

Since it is written in the classical (wenyan wen) instead of the vernacular language and dedicated to the supernatural, with the anti-ghost rhetoric of the May Fourth Movement in the 1920 s and the ghost-purging campaigns of the Maoist China, zhiguai as a genre about ghosts had largely been banished from the Chinese literary arena in the major part of the twentieth century, waiting for a resurgence

${ }^{11}$ Confucius famously voiced his disdain for supernatural subjects in the Analects: "The subjects on which the Master did not talk were: extraordinary things, feats of strength, disorder, and spiritual beings" (in James Legge trans., 201).

12 This book has been widely translated into English since the late $19^{\text {th }}$ century. The title has been rendered variously into "Strange Stories from a Chinese Studio" (Herbert Giles) or "Strange Tales from a Chinese Studio" (John Minford). I opt for "Records of the Strange" in my rendering of the title to emphasize the generic feature.

${ }_{13}$ The title explicitly gestures to Confucius' admonition quoted above. 
until after The Great Proletarian Cultural Revolution (1966-1976) ${ }^{14}$. Yet, the canonization and wide distribution of one zhiguai collection, $\mathrm{Pu}$ Songling's Records of the Strange from the Liao Studio (very often "translated" and published in vernacular language for contemporary readers) in the Maoist China 15 ensure the average Chinese readers' familiarity with the genre. In this context, zhiguai stories partake of the quality of what Freud calls uncanny when it is encountered in a contemporary cultural milieu: it is a returning of the repressed familiar one. By ostensibly gesturing to the zhiguai metatexts in their title, choice of language, style and plotting, Ma's New Records of the Strange and Jinyi's Records of Oxen and Snakes teasingly activate in their readers' minds memories of old zhiguai tales while narrating strange contemporary or near-contemporary events, and the surface fantastical stories help to draw attention away from as well as towards the subversive political satire underneath.

Ma's column New Records of the Strange is a collection of sketches of contemporary foibles that humorously titillates people's familiarity with the old genre zhiguai. The collection contains all the familiar ingredients of zhiguai - the title derived from Pu Songling's Records of the Strange from the Liao Studio ${ }^{16}$, the quaint diction reminiscent of one "translated" from classical Chinese, and the typical zhiguai plot containing three universal actors summarized by Patrick Hanan as generic to the Chinese demon story: the young man, the demon, and the Taoist exorcist (44). Yet the stories deal with typical worries and anxieties of contemporary Chinese youth in a technicalized society: the bubble of Internet start-ups, social pressure on young women to marry, young men's obsession with adult videos and, most appropriately for an Internet literary genre, the satire on contemporary state-

14 Upholding "Science" and "Democracy" as its twin pillars, the May Fourth thinkers tend to use an anti-ghost rhetoric to promote their modernizing discourse. For instance, one of the radical thinkers, Zhou Zuoren (周作人) famously advocated for a new "humane literature" (人的文学) to replace the old "inhumane literature" (非人的文学) which includes ghost literature. This anti-ghost discourse was renewed in Mao's period, with ghosts becoming an analogy for any political enemy that needed to be purged. See Luo, "The Ghost of Liaozhai: Pu Songling's Ghostlore and Its History of Reception" (204-249) for a review of the anti-ghost discourse in the twentieth-century China.

${ }_{15}$ While the Maoist era maintained the general anti-ghost sentiments, Pu's Records of the Strange was appropriated and canonized by Mao Zedong as an exemplar book of social criticism using ghosts as a metaphor for political enemies. A team of scholars under Mao's instruction even compiled a collection of stories entitled "Stories about People Who Do Not Fear Ghosts" containing abridged stories from the entire zhiguai tradition. See Luo 218-226.

${ }^{16}$ New Records of the Strange (新志异) and Records of the Strange from the Liao Studio (聊斋 志异） share the same compound "zhiyi" (records of the strange), which is a generic term in the genre zhiguai. 
engineered ideological campaigns and Internet censorship. Especially for the last purpose, the mingling of materials old and new makes the contemporary online ghost stories a special vehicle for targeting and evading censorship simultaneously, as are to be shown in two stories: "Ghosts in Wuhan University" and "The Mandarin in the Case".

"Ghosts in Wuhan University" plays on traditional zhiguai"s dialectical relation with orthodoxy through the ironic and peripheral state of the ghost. Since the 18th National Congress of the Communist Party of China in 2012 and the current Chinese president Xi Jinping's presidency, a set of moral values collected under the title "Core Values of Chinese Socialism" has been militantly promoted by the government in all social sectors ${ }^{17}$. In the heat of this "educational" campaign in 2014, there was even news that students in Wuhan University had been forced to recite the "Core Values" by school authorities, which led to a wave of public criticism.

"Ghosts in Wuhan University" (published online in 2014) responds to this contemporary farce. The Taoist exorcist in the story named Bao Shu confronts a group of ghosts haunting the library of Wuhan University with the question why they have been causing such a disorder for people, and the shamefaced ghosts answer that an overzealous local magistrate had received the 24 chapters of "Values to Promote Harmony amongst the People" from heaven in his dream and had been since forcing his people to recite these values day and night with the hope that memorial arches of his merits would thus reach the heavenly palace. As a result, the poor ghosts are greatly agitated by the recitation and have to hide in the University Library. While this is a thinly-veiled restaging of the above-mentioned political campaign, the story's ending remark brings home the author's protest: "Bao Shu then asks: «If so, why would you recite these values too?» The ghost answers: «If people recite these values, ghosts can be exorcised; if ghosts recite these values, people can be exorcised»" 18 .

Here, the ghost, the usual character in zhiguai stories that fulfils the function of

17 These values are condensed into twelve words: "prosperity, democracy, civility, harmony, freedom, equality, justice, the rule of law, patriotism, dedication, integrity and friendship” (富强，民主 ，文明，和谐，自由，平等，公正，法治，爱国，敬业，诚信，友善). Because they contain 24 Chinese characters, they are also referred to as the "24-word core socialist values". For an authoritative interpretation of these values, see for instance, Du Yifei, "24-Core Socialist Values Engraved on People's Mind," People.cn. March 2nd 2016, People's Daily (http://en.people.cn/n3/2016/0302/c98649-9023926.html).

18 宝树又说: “既然如此, 那你们为何也要诵咒呢?” 鬼怪道: “人诵此咒, 可以驱鬼; 鬼诵此咒, 可以驱人. If not otherwise stated, translations in this article are all mine. 
the troublemaker, turns out in the end to be not the originator of disorder but a victim of it, and ironically, the values issued from the authority to dispel ghosts could be re-utilized by what is exorcised as a weapon against the exorcist. Like the ambiguous and unorthodox position assumed by the ghost in traditional Chinese culture, the ambiguous position of contemporary online zhiguai like this one also makes it a double-edged sword that flaunts its own frivolity while stinging the authority with its very playfulness and unorthodoxy.

This paradoxical critiquing and self-deconstructing function is also the key element that makes "The Mandarin in the Case" an effective direct confrontation with a most sensitive topic: Internet censorship. In this story, a $\mathrm{Mr} \mathrm{Li}$ in Beijing is troubled by a mysterious scraping sound in his bedroom. His friend, Mr Liu, helps to trace a black shadow in Li's computer case, which later proves to be a fully-clad little mandarin sitting in the niche between the hard disk and the network interface card waving a sword. The mandarin tells Liu that he is the kitchen god, who finds his new post nowadays inside people's computer cases to cut the network connection and report to the Jade Emperor whenever sensitive or dissenting remarks are posted online by the computer user ${ }^{19}$, and that the previous mysterious sound comes precisely from his cutting the ethernet cable. The comic story ostensibly points to something old and known in Chinese culture: the traditional duty of the kitchen god to report on gossips within each household and a similar story in Pu Songling's Records of the Strange entitled "The Little Mandarin" in which a man chances to see a finger-sized troop of mandarins in his bedroom. Here, the sensitive issue of contemporary censorship, framed in a recognizably traditional generic envelop, helps to parody censorship while at the same time evading it, and the reader's knowledge of zhiguai as a paradoxically unorthodox and didactic genre is key in this double function. On the one hand, a story about a miniature mandarin who hides in people's computer cases is obviously fantastic, ridiculous, and not a mimetic rendering of reality, thus avoiding alarm from the authority; while on the other hand, however bizarre the supernatural entities in a zhiguai story may be, the zhiguai genre is understood to be allegorical and didactic ${ }^{20}$, so the story's mock of contemporary

19 Temporary suspension of network connection is a usual method of virtual censorship employed by the Chinese government. See Qiu (15-16) on the penalties for political discussion levelled by the state.

20 Didacticism is an important tenor of traditional zhiguai, with "teaching by the ways of gods and ghosts" upheld by many zhiguai writers as a moral justification for writing these otherwise 
curtailment of freedom of speech is nevertheless poignantly felt.

While Ma's New Records of the Strange mocks the contemporary political environment, Jinyi's Records of Oxen and Snakes targets the political atrocities of a recent past: the period of the Cultural Revolution from 1966 to 1976. Ma's allegorical ghost stories have to walk a tightrope between explicit protest and playful frivolity as the target of the satire is dangerously near; yet Jinyi's allegorical ghost stories about the Cultural Revolution are no less sensitive, for in the post-Mao China, although the party's political campaigns and policies in the Cultural Revolution have been officially admitted as wrong ${ }^{21}$, the authority, however, does not encourage further exposition and excavation of that dark past. After condemning a small group - the "Gang of Four" 22 and Lin Biao as the evil schemer and "counter-revolutionaries" of the Cultural Revolution and promoting a sentimental catharsis in the trend of scar literature and films dealing with the catastrophe in the late 1970 s and early $1980 \mathrm{~s}^{23}$, the party promotes an ideology that reorients people to "look forward" and concentrate on economic construction instead of dwelling on the catastrophic past (Huang 8-9; Zeng 34-5). It is not that public discussion and artistic representations of the Cultural Revolution are banned in contemporary China, but that, with an officially ordained frame of history, serious appraisal and questioning of the past especially of the party's power and validity in it - is made difficult. In Yiju Huang's words, this deliberate dearth on the Cultural Revolution turns it not into a healed scar, but an open and festering wound (10), an unworked-through trauma with "the unappeased ghosts moaning in the dark" (13). In this sense, Jinyi's bizarre ghost stories hark back to another function of the traditional zhiguai in its conception: stories of ghosts working as a riotous double of the histories of the state, conjuring up

unorthodox and frivolous stories about ghosts. On the didacticism of zhiguai, see Chan (1998), The Discourse on Foxes and Ghosts: Ji Yun and Eighteenth-Century Literati Storytelling.

${ }^{21}$ For the official verdict of the movement, see the Communist Party of China Central Committee's resolution passed on June $27^{\text {th }} 1981$, "Resolution on Certain Questions in the History of Our Party since the Founding of the PRC"(关于建国以来党的若干历史问题的决议), available at <http://cpc.people.com.cn/GB/64162/64168/64563/65374/4526453.html> (accessed May 8 ${ }^{\text {th }}$ 2019). The document, while criticizing Mao's mistakes in the Cultural Revolution, maintains a fair degree of ambivalence towards a total negation of Mao, which, as Zeng (35) notes, would threaten the power of the Party. Such an ambivalence persists in the Party's later censorship rules concerning representations of the Cultural Revolution, which makes the topic deemed more sensitive.

${ }^{22}$ The Gang of Four refers to Jiang Qing (Mao Zedong's wife), Zhang Chunqiao, Yao Wenyuan, and Wang Hongwen, party officials who rose to power during the Cultural Revolution.

${ }^{23}$ Scar literature (伤痕文学) is a body of writing, emerging immediately after the death of Mao, that addresses ordinary people's, especially the sent down youths', trauma and loss during the Cultural Revolution. According to Jing Meng (672), films dealing with the Cultural Revolution decreased in number after the mid-1980s due to tighter control. 
ghosts - violence and historical injustices - silenced in the official version of history.

Jinyi's 41 stories are not all about the Cultural Revolution, yet the column's title Records of Oxen and Snakes contains a covert reference to that dark era. "Conquer all the oxen ghosts and snake gods" 24 had once been a popular political slogan during the Cultural Revolution, so the phrase "records of oxen and snakes" refers through its deliberate omission to "records of ghosts and gods". This coded language achieves two things: first, it indirectly informs the reader that the stories are indeed about ghosts and gods during the Cultural Revolution, and second, the deliberate act of omission carries the message that the "ghosts" to be talked about here are something obliterated and having no place in contemporary discourse, a covert reference to contemporary as well as historical censorship. The column's political undertone is again hinted at in the introduction section, where the author writes: "Black nights give me black eyes, and I use them to seek black stories"25. The line is derived from the famous poem "One Generation" (1979), written in the wake of the Cultural Revolution by the Chinese "Misty" Poet Gu Cheng, which contains only two lines: "Black nights give me black eyes,/ yet I use them to seek the light."26. As with Ma's New Records of the Strange, Oxen and Snakes has appropriated copiously the traditional zhiguai aesthetics such as the choice of vocabulary, character types and plot conventions, yet the coded reference to the Cultural Revolution in the paratexts of the stories also underlines its political aim: to expose and to excavate the unspeakable.

Many stories in the collection deal with tabooed subjects such as sexual violence, gruesome murder and the corruption of revolutionary cadres. These otherwise too offensive or voyeuristic topics in more realistic or highbrow genres of fiction find an accommodating place in the riotous and playful zhiguai. Like other light web-fiction, the stories here appropriate the slightly greater licence afforded by the genre to amuse and entertain their readers. Yet what is unique and original about this appropriation of an old form is the ambiguous state of ghosts set in a politicallyextreme period eager to conquer all ghosts. Traditionally, the supernatural elements in zhiguai have often been used as a literary device to give license to the depiction of excessive desires policed by the Confucian orthodoxy, so that a sexually active ghost

\footnotetext{
24 “打倒一切牛鬼蛇神.”

25 “黑夜给了我黑色的眼睛, 我用它寻找黑色的故事。”

26 “黑夜给了我黑色的眼睛, /我却用它寻找光明。”
} 
woman in Pu's Records of the Strange may be read as men's fantasy of female sexual promiscuity not befitting an ideal Confucian woman. Yet during the Cultural Revolution, when ghosts together with Confucian teachings were announced to be the enemy of the new society and unlimited political power gave free rein to excessive sexual desires and violence, a story of sex no longer needs the story of ghosts as a pretence, instead, it is the other way around. In this context, the old dynamic between desire and the supernatural - the two prominent elements of zhiguai assumes a double structure. On the surface level of the story, we still see the old dynamic: stories of ghosts veil over scandalous stories revolving around sex and power struggle, while beneath this familiar plot, we see that the sexual violence rampant in the period of Cultural Revolution points to another more secret ghost within the story: the distortion of law, justice, and human conscience during that dark period which could not be properly spoken of.

"The Blood Turtle" and "Fornication with the Ghost" are two stories centring on the sexual violence imposed on women by radical political leaders during the Cultural Revolution. In "The Blood Turtle", the leader of the Revolutionary Committee of the Red Star Commune dies abruptly one night in the yard of a local family, his penis severed and missing. The police detective who is also the narrator of the story is later made to believe that the leader had met his death when he tried to rape the deaf daughter-in-law of that family, for the so-called blood turtle fixed in her vagina by her father-in-law ate the man's penis in the act of copulation. The blood turtle is a mythic creature recorded in many zhiguai stories over the centuries ${ }^{27}$. It is also called "maintaining chastity" and is believed to be a demonical excretion of women's suppressed sexual desire, usually found in the vaginas of old widows and nuns. It is not difficult to see in the so-called "blood turtle" - a literal vagina dentata - the demonization of women's sexual desire and displacement of men's fear of women in a society that worshipped and enforced women's chastity. The chastity requirement imposed on women was so extreme and unnatural so that even for women who managed to keep it, they elicited more fear than admiration from men. However, when the story of the blood turtle is transferred into the context of the

${ }_{27}$ For instance, Qing-dynasty writer Xu Feng'en's zhiguai collection Local Records (里乘 1876) includes a similar story called “Maintaining Chastity” (守贞) and Li Qingchen's Records of the Strange from the Drunken Tea（醉茶志怪 1892） includes a story entitled “A Sichuan Woman” (四川女) about a similar creature. 
Cultural Revolution, it becomes witness to another form of sexual abuse of women in a new political environment. The beautiful daughter-in-law had been the daughter of a landlord, whose family had been killed early on in the political campaign and whose body was deemed a legitimate prey by the commune leader. While the lurid description of rape and death by blood turtles serves as the central "strangeness" of the story that catches readers' attention and even successfully convinces the detective narrator, it is revealed at the end of the story that the blood turtle is only a hoax to veil over a real rape and murder. In this way, the story subtly conveys the message that, in an age plagued with madness, even a strange and lurid case involving the fantastic creature blood turtle pales against the more absurd and less credible reality of the Cultural Revolution.

"Fornication with the Ghost" contains a similar eye-catching story hinging on erotica set shortly after the Cultural Revolution. A recently-married man finds his bride visited nightly by an invisible ghost, who fornicates with her and gives her so much pleasure so that the wife refuses to consummate their marriage. In order to cure the wife of the "ghost disease" the man asks for the help of a Taoist adept, Ye Celong, who had been a victim of the rigorous anti-ghost campaign of the Maoist era, ruthlessly persecuted during the Cultural Revolution for his "feudal superstitions". Here, the Taoist assumes the role of the police detective and, after some battle with the invisible ghost, a buried murder during the Cultural Revolution is uncovered: the ghost is the wife Binbin's lesbian lover Xiaoxue and both had been the sent down youth dispatched to plant trees in the desert during the Cultural Revolution. When Binbin's father Master Liu, a government officer, learned about this secret love, he raped and killed Xiaoxue and buried her secretly in the desert, and the ghost of Xiaoxue since then has taken residence in the heart of Binbin. Again, the outrageous story of ghost fornication and lesbian love highlights the current violence and intolerance towards homosexuality, while gesturing at the same time to the past violence towards women during the Cultural Revolution when those in power could blatantly tread on those who did not.

In the story "Grievance," the surface story again revolves around women's vulnerability to sexual violence during the Cultural Revolution when the communist cadres assumed unrestrained power, yet the unspeakableness of historical injustice is directly confronted at the end of the story, which may summarize the central interrogation of many stories within this collection. Qi Yufen, the beautiful widow of 
a former KMT soldier ${ }^{28}$, is ruthlessly persecuted together with Ye Celong, the Taoist, when Mr Liu, leader of the People's Commune dies mysteriously after visiting her at night. Shortly, several men who had had an affair with the widow all die a gruesome death, and the police detective and the Taoist together trace the murders to a grudging ghost, the dead husband of Qi Yufen. With further investigation, a secret buried further back in history surfaces: Liu had come into power at the beginning of the Cultural Revolution when he announced that he had once killed 15 KMT soldiers including Yufen's husband, yet what no one knows is that the 15 soldiers had been ambushing a troop of Japanese during the Japanese Invasion (1937-1945) and were sold out to the Japanese by Liu. It is the suppressed grievance of the dead Soldier Bian Jiefei that materializes into an avenging ghost who kills all the men who had raped Yufen.

The resolution of this grievance at the end of the story emphasizes the significance of those historical atrocities and one's moral responsibility to speak out against them yet, at the same time, it also highlights the impossibility to speak in full explicitness. Knowing that the grudge of being wronged historically is the demonic power that drives the ghost, the detective and the Taoist try to outmanoeuvre the ghost by speaking out the truth of his death yet, just as they are about to succeed, they suddenly realize the moral danger of doing so. The detective reminds the Taoist: "The truth is known only between you and me. How can it ever be made public?"29. And the Taoist dawns on the inefficiency of the justice rendered by their announcement and wonders: "Why should I kill the ghost? Isn't it better to have him accompany Yufen and protect her?" 30 and, kneeling in front of the widow and the ghost, he admits: "I can never dispel your grudge." 31 The ghost exorcist's apology to the ghost may be read as an indirect apology of the author to the project of excavating historical injustices underlying the whole collection: to tell ghost stories of that unexamined and hurriedly-buried recent past is a moral obligation of the present; yet, in contemporary as well as in the Cultural Revolution settings, full exposure and expression is never possible, and ghosts will be forever needed in a

${ }^{28}$ KMT is the abbreviation for Kuomintang, or Chinese Nationalist Party, the rival of the Communist Party of China (CPC) during the Chinese civil war (1945-1949) and, after the defeat of the civil war, the party relocated to Taiwan in 1949.

29 “这真相只有你知我知, 能公开说出来吗?”

30 “我为什么要降服他啊, 让他好好陪着齐玉芬不很好吗, 谁还敢欺负她? ”

31 “你们的怨气我解不了。” 
world where speeches are censored. As with all the stories mentioned above, Jinyi's Oxen and Snakes uses a coded Aesopian language to tell double-layered ghost stories: on the margins of the lurid and sometimes obscene stories about ghosts and copulation lie graver stories of ghosts of political injustice.

Both Jinyi's apology and the precariousness of Ma's New Records of the Strange ${ }^{2}$ signal the prevalence of today's Internet censorship. Yet as literature produced with censorship as an inhering element of its signification system, both collections re-appropriate the political resources of the old fictional genre zhiguai into an effective modern political documentation (especially in Ma's case) and commentary. In this process, the online allegorical ghost stories not only give expression to the pent-up emotions and discontents in the current society but also create something new: a new allegorical literature that mocks and dodges censorship at the same time by flaunting its self-reflective understanding of its imitation of and deviation from the old form, and this testifies to the elasticity and power of literature as a discourse in a menacing socio-political environment. In a political sense, as a type of the hidden transcript of the subordinates made public, the reincarnated ghost stories are an innovative art of resistance. In Scott's words, this type of discourse "carves out a public, if provisional, space for the autonomous cultural expression of dissent. If it is disguised, it is at least not hidden; it is spoken to power. This is no small achievement of voice under domination" (166). When censorship is becoming more penetrating and insinuating today, the case of these allegorical online ghost stories shows that literature is reshaping itself too, to create new space for and a new mechanism of expression.

\section{References:}

Berg, Daria. "Consuming Secrets: China's New Print Culture at the Turn of the Twenty-First Century." From Woodblocks to the Internet: Chinese Publishing and Print Culture in Transition, circa 1800 to 2008. Edited by Cynthia Brokaw and Christopher A. Reed. Brill, 2010: 315-32.

Briggs, Julia. Night Visitors: The Rise and Fall of the English Ghost Story. Faber, 1977 .

${ }^{2}$ Ma's "Ghosts in Wuhan University," "Mandarin in the Case" and "Three Temples" from the collection were temporarily removed from his column in 2015, yet the whole collection is later posted by the author in various social networks and is no longer censored. These stories remain easily accessible throughout the Chinese Internet now. 
Chan, Leo Tak-hung. The Discourse on Foxes and Ghosts: Ji Yun and EighteenthCentury Literati Storytelling. The Chinese University of Hong Kong (also published by University of Hawaii Press), 1998.

China Internet Network Information Center (CNNIC). $41^{\text {st }}$ Statistical Report on Internet Development in China (January 2018). CNNI. http://cnnic.com.cn/IDR/ReportDownloads/201807/Po20180711391069195 909.pdf pdf.

"«Cleansing the Internet»: Multiple Ministries Cooperate to Strike the Original Sin of the Internet” (“净网行动”冲击波 多部委联合打击互联网原罪). April 28th 2014. Sohu.com. Web. Accessed March $19^{\text {th }} 2019$ http://it.sohu.com/20140428/n398892469.shtml

Communist Party of China Central Committee. "Resolution on Certain Questions in the History of Our Party since the Founding of the PRC.” (关于建国以来党的若 干 历史问 题 的决议 ) June $27^{\text {th }} 1981$. People.com.cn: http://cpc.people.com.cn/GB/64162/64168/64563/65374/4526448.html. Accessed May $8^{\text {th }} 2019$.

Dewoskin, Kenneth J. "The Six Dynasties Chih-Kuai and the Birth of Fiction." Chinese Narrative: Critical and Theoretical Essays. Ed. Andrew H. Plaks. Princeton University Press, 1977: 21-52.

$\mathrm{Gu}$, Cheng (顾城). “One Generation” (一代人). Gucheng's Poems (顾城的诗). $2^{\text {nd }}$ ed. People's Literature, 2010: 26.

Hanan, Patrick. The Chinese Vernacular Story. Harvard University Press, 1981.

Hockx, Michel. Internet Literature in China. Columbia University Press, 2015.

Huang, Yiju. Tapestry of Light: Aesthetic Afterlives of the Cultural Revolution. Brill, 2015.

Jinyi (锦翼). Records of Oxen and Snakes (牛神录). Douban.com. Web. February $2^{\text {nd }}$ 2019: https://read.douban.com/column/279538/.

Kong, Shuyu. Consuming Literature: Best Sellers and the Commercialization of Literary Production in Contemporary China. Stanford University Press, 2005 .

Legge, James, transl. and ed. Confucius: Confucian Analects, The Great Learning \& The Doctrine of the Mean. Dover, 1971. Rpt. of the 2nd rev. Clarendon 1893 edition. 
Lossef, Lev. On the Beneficence of Censorship: Aesopian Language in Modern Russian Literature. Trans. Jane Bobko. Sagner, 1984.

Li, Qingchen (李庆辰). “A Sichuan Woman” (四川女). Records of the Strange from the Drunken Tea (醉茶志怪 1892). Qilu Books, 2004: 110.

Liu, Yuan-ju. "Allegorical Narratives in Six Dynasties Anomaly Tales." Rethinking Ghosts in World Religions. Ed. Muzhou Pu. Brill, 2009: 269-97.

Lu, Xun (鲁迅). A Brief History of Chinese Fiction (中国小说史略). Shanghai Ancient Books, 1973.

Luo, Hui. "The Ghost of Liaozhai: Pu Songling's Ghostlore and Its History of Reception." PhD Diss., University of Toronto, 2009.

Ma, Boyong (马伯庸). New Records of the Strange (新志异). Zhihu.com. n.d. Web. February $27^{\text {th }}$ 2019: < https://zhuanlan.zhihu.com/p/27245077>.

Meng, Jing. "Prohibition and Production of the Past: Representation of the Cultural Revolution in TV Dramas." Media, Culture \& Society 37.5, 2015: 671-85.

Ng, Lynda. "China's Elusive Truths: Censorship, Value and Literature in the Internet Age." Censorship and the Limits of the Literary: A Global View. Edited by Nicole Moore. Bloomsbury Academic, 2015: 233-46.

$\mathrm{Pu}$, Songling. "The Little Mandarin." Strange Stories from a Chinese Studio. Translated by John Minford. Penguin Books, 2006: 200-201.

Qiu, Jack Linchuan. "Virtual Censorship in China: Keeping the Gate between the Cyberspaces." International Journal of Communications Law and Policy 4, Winter 1999: 1-25.

Scott, James C. Domination and the Arts of Resistance: Hidden Transcripts. Yale University Press, 1990.

Wacker, Gudrun. "Resistance Is Futile: Control and Censorship of the Internet in China." From Woodblocks to the Internet: Chinese Publishing and Print Culture in Transition, Circa 1800 to 2008. Edited by Cynthia Joanne Brokaw and Christopher A. Reed. Brill, 2010: 353-81.

Xu, Feng'en (许奉恩). “Maintaining Chastity” (守贞). Local Records (里乘 1874). Qilu Books, 2004: 233-234.

Yang, Guobin. "Chinese Internet Literature and the Changing Field of Print Culture." From Woodblocks to the Internet: Chinese Publishing and Print Culture in Transition, Circa 1800 to 2008. Edited by Cynthia Joanne Brokaw and 
METACRITIC JOURNAL FOR COMPARATIVE STUDIES AND THEORY 5.1

Christopher A. Reed. Brill, 2010: 333-51.

Zeng, Li. The Past Revisited: Popular Memory of the Cultural Revolution in Contemporary China. PhD diss. Northwestern University, 2008. 